\title{
Production of cloned mice from embryonic stem cells arrested at metaphase
}

\author{
Y. Ono ${ }^{1}$, N. Shimozawa ${ }^{1,2}$, K. Muguruma ${ }^{2}$, S. Kimoto ${ }^{1}$, K. Hioki², \\ M. Tachibana ${ }^{3}$, Y. Shinkai ${ }^{3}$, M. Ito ${ }^{2}$ and T. Kono ${ }^{1,4^{*}}$ \\ ${ }^{1}$ Department of Animal Science, Tokyo University of Agriculture, 1737 Funako Atsugi-shi, \\ Kanagawa 243-0034, Japan; ${ }^{2}$ Central Institute for Experimental Animals, 1430 Nogawa, \\ Miyamae-ku, Kawasaki-shi, Kanagawa 216-0001, Japan; ${ }^{3}$ nstitute for Virus Research, Kyoto \\ University, 53 Shogoin Kawara-cho, Sakyo-ku, Kyoto 606-8397, Japan; and \\ ${ }^{4}$ Department of Bioscience, Tokyo University of Agriculture, 1-1-1, Sakuragaoka, \\ Setagaya-ku, Tokyo 156-8502, Japan
}

In mammals, cloned individuals can be produced from somatic cells. The combined use of gene targeting in embryonic stem cells and cloning contributes to the investigation of gene function in mammals. However, one of the major limitations to cloning is the low viability of cloned embryos, leading typically to high rates of pre- and postnatal death. The present study investigated whether cloning efficiency is influenced by the procedural differences involved in using transfected embryonic stem cells arrested at $M$ phase for cloning by both single and serial transfer. In contrast to a previous study, in which fibroblasts were used, in the present study using embryonic stem cells there was no difference in the rate of production of cloned pups after the use of a single or serial nuclear transfer, although the proportion of blastocysts (70\% versus $51 \%)$ was significantly higher $(P<0.001)$ after serial nuclear transfer. After embryo transfer of $\mathbf{4 4 5}$ blastocysts, 218 (49\%) implanted and $27 \quad(6 \%$ of blastocysts transferred) live pups were born. Of these 27 pups, 23 developed to adults of apparently normal fertility. Of these adults, $39 \%(n=9)$ were derived from targeted embryonic stem cells, which is similar to the proportion of targeted embryonic stem cells in the population used for cloning. This study showed that cloning with embryonic stem cells is a viable procedure resulting in the production of transgenic cloned adults.

\section{Introduction}

After the production of cloned sheep from cultured embryonic disc cells (Campbell et al., 1996), a succession of other individuals, including sheep (Schnieke et al., 1997; Wilmut et al., 1997), cattle (Kato et al., 1998), goats (Baguisi et al., 1999) and mice (Wakayama et al., 1998; Ogura et al., 2000), were cloned from somatic cells. These studies revealed the capacity of unfertilized oocytes to reprogramme the DNA of differentiated cells, although the mechanism by which this occurs remains poorly understood (Wakayama et al., 2000). One of the practical uses for cloning is its application as part of a gene targeting strategy, especially in mice, since functional embryonic stem (ES) cells have been established and used widely for the analysis of gene function in vivo. This potential use was realized by Wakayama et al. (1999) and Rideout et al. (2000), who produced cloned pups from ES cells established from a 129 sub-strain and 129XC57BL/6 hybrid strain mice. However, Wakayama et al. (1999) also reported disadvantages in cloning from ES cells. A large

*Correspondence

Email: tomohiro@nodai.ac.jp proportion of the clones produced from 129 ES cells died postnatally for reasons as yet unknown, and it has not proved possible to produce clones from the TT2 ES cell line established from B6CBF1 hybrid strain mouse embryos. In general, fetal loss occurs throughout the gestation period in somatic cell cloning (Wakayama et al., 1998; Ogura et al., 2000; Ono et al., 2001).

Cloned mice can be generated from fetal fibroblast cells synchronized at metaphase by serial nuclear transfer (Ono et al., 2001). The donor nuclei are transferred into ovulated oocytes and, after artificial activation, the nucleus formed is again transferred to enucleated fertilized one-cell embryos. The present study used the original procedure (Ono et al., 2001) to examine whether cloned mice can be produced from TT2 ES cells, which had been targeted previously at the G9a gene (Tachibana et al., 2001), homologous to the human G9A, a novel mammalian lysine-preferring histone methyltransferase.

\section{Materials and Methods}

\section{Animals}

Adult female and male B6CBF1 (C57BL/6XCBA) and ICR mice were obtained from SLC Japan Inc. (Shizuoka). All 

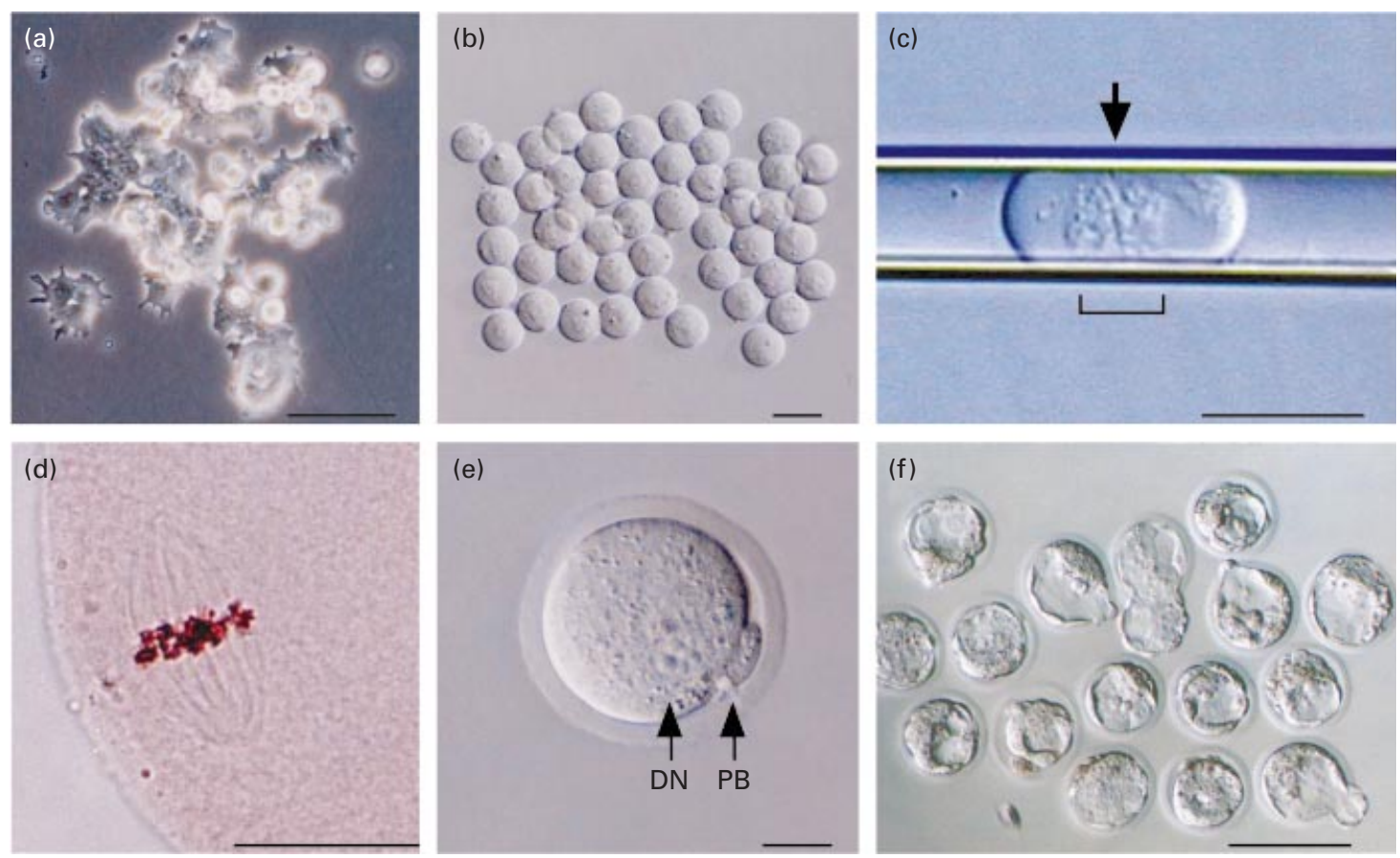

Fig. 1. Construction of cloned embryos from embryonic stem (ES) cells arrested at metaphase. (a) ES cells were exposed to the synthetic microtubule inhibitor nocodazole at $0.4 \mu \mathrm{g} \mathrm{ml}^{-1}$ for $2 \mathrm{~h}$ before nuclear transfer. Cells going through the process of cell division are attached less firmly to the substratum. (b) Metaphase cells 18-20 $\mu \mathrm{m}$ in diameter were selected for nuclear transfer as donor cells. (c) Condensed metaphase chromosomes were observed when a donor cell (arrow) was sucked into a injection pipette. Chromosomes are viewed here by Hoffman modulation contrast microscopy. (d) Constructed oocyte formed by the nuclear transfer of the ES cell into an enucleated oocyte. Transformation of the normal metaphase spindle was observed in $80 \%$ of oocytes. (e) Constructed oocyte activated with $10 \mathrm{mmol}$ strontium $\mathrm{I}^{-1}$ formed a single diploid pronucleus (DN) after extruding the extra polar body (PB). (f) Blastocysts derived from constructed oocytes using ES cells. Scale bars represent $100 \mu \mathrm{m}(\mathrm{a}, \mathrm{f})$ and $20 \mu \mathrm{m}(\mathrm{b}-\mathrm{e})$.

mice were kept under controlled temperature $\left(23 \pm 2^{\circ} \mathrm{C}\right)$ and lighting conditions of $12 \mathrm{~h}$ light:12 $\mathrm{h}$ dark during experiments and were given food and water ad libitum. All mice were maintained and used in accordance with the Guide for Care and Use of Laboratory Animals by the Japanese Association for Laboratory Animal Science.

\section{Preparation of donor cells}

The TT2 ES cells, established from hybrid strain B6CBF1 male mouse embryos, had been targeted previously at the G9a gene. However, the ES cell line had not been selected. ES cells were cultured in collagen-coated dishes without a feeder layer for 3 days in Knockout-DMEM medium (Gibco BRL, Grand Island, NY) supplemented with $15 \%(\mathrm{v} / \mathrm{v})$ fetal bovine serum (Gibco) and leukaemia inhibitory factor (Wako Pure Chemical Industries, Osaka) at a concentration of $10^{3} \mathrm{U} \mathrm{ml}^{-1}$ and the following reagents: $2 \mathrm{mmol}$ L-glutamine (Gibco) $\mathrm{I}^{-1}, 1 \%(\mathrm{v} / \mathrm{v})$ non-essential amino acid solution (Gibco) and $5.5 \times 10^{-5} \mathrm{~mol}^{2}$-mercaptoethanol I-1 solution (Wako). ES cells were cultured with medium containing $0.4 \mu \mathrm{g}$ nocodazole $\mathrm{ml}^{-1}$ (Sigma Chemical Co., St Louis, MO), a microtubule polymerization inhibitor, for $2 \mathrm{~h}$ so that the cells were synchronized at metaphase. Cells floating in the medium were collected (Fig. 1b). When taken into a transfer pipette, only the cells arrested at metaphase were selected and used as nuclear donors (Fig. 1c).

\section{Nuclear transfer and embryo transfer}

Cloned embryos were constructed by single or serial nuclear transfer using ES cells arrested at metaphase (Kwon and Kono, 1996; Ono et al., 2001). The oocyte donors were 6-8-week-old female B6CBF1 mice. Fertilized one-cell embryos were produced by in vitro fertilization using 8-10week-old B6CBF1 females and males as oocyte and sperm donors. Micromanipulations were performed in $\mathrm{M} 2$ medium containing $5 \mu \mathrm{g}$ cytochalasin $\mathrm{B} \mathrm{ml}^{-1}$ (Sigma) and $0.4 \mu \mathrm{g}$ nocodazole $\mathrm{ml}^{-1}$ in a micromanipulation chamber. After enucleation of metaphase II chromosomes, an ES cell arrested at metaphase was introduced into the perivitelline space of the enucleated oocyte with inactivated Sendai virus (HV), 2700 haemagglutinating activity units $\mathrm{ml}^{-1}$ ). The oocytes that fused successfully with a donor cell were incubated for $2 \mathrm{~h}$. After brief culture, the oocytes were activated artificially with $10 \mathrm{mmol}$ strontium $\mathrm{I}^{-1}$ for $6 \mathrm{~h}$ and 
Table 1. Construction of mouse embryos by single or serial nuclear transfer using TT2 embryonic stem cells

\begin{tabular}{lccc}
\hline Nuclear transfers & $\begin{array}{c}\text { Number of oocytes } \\
\text { fused at first nuclear } \\
\text { transfer/manipulated }(\%)\end{array}$ & $\begin{array}{c}\text { Number of } \\
\text { oocytes activated } \\
\text { normally }(\%)\end{array}$ & $\begin{array}{c}\text { Number of } \\
\text { oocytes fused at } \\
\text { second nuclear transfer }\end{array}$ \\
\hline Serial & $395 / 519(76)$ & $369(93)$ & $311(84)$ \\
Single & $489 / 597(82)$ & $458(94)$ & - \\
\hline
\end{tabular}

Table 2. Development of cloned mouse embryos produced from TT2 embryonic stem cells

\begin{tabular}{|c|c|c|c|c|c|c|c|c|c|}
\hline \multirow[b]{2}{*}{$\begin{array}{l}\text { Nuclear } \\
\text { transfers }\end{array}$} & \multirow{2}{*}{$\begin{array}{c}\text { Number of } \\
\text { cloned embryos } \\
\text { cultured }\end{array}$} & \multicolumn{2}{|c|}{$\begin{array}{l}\text { Number of oocytes } \\
\text { developed to }\end{array}$} & \multirow{2}{*}{$\begin{array}{l}\text { Number of } \\
\text { transferred } \\
\text { embryos }\end{array}$} & \multirow{2}{*}{$\begin{array}{l}\text { Number of } \\
\text { pregnancies/ } \\
\text { recipients }\end{array}$} & \multirow{2}{*}{$\begin{array}{l}\text { Number of } \\
\text { implantation } \\
\text { sites }\end{array}$} & \multicolumn{2}{|c|}{$\begin{array}{c}\text { Number of pups } \\
\text { at term }\end{array}$} & \multirow[b]{2}{*}{$\begin{array}{l}\text { Number } \\
\text { of adults }\end{array}$} \\
\hline & & $\begin{array}{l}\text { Two-cell } \\
\text { embryo }\end{array}$ & Blastocyst & & & & Dead & Alive & \\
\hline Serial & 311 & 307 (99) & $217(70)^{\mathrm{a}}$ & 213 & $13 / 17$ & $110(52)$ & $1(0.3)$ & $10(3.2)$ & $9(2.9)$ \\
\hline Single & 458 & 452 (99) & $232(51)^{b}$ & 232 & $13 / 19$ & $108(47)$ & $0(0)$ & $17(3.7)$ & $14(3.1)$ \\
\hline
\end{tabular}

Values in parentheses are percentages of cloned embryos cultured, except for in 'Number of implantation sites' column, in which values in parentheses are percentages per blastocysts transferred.

abValues with different superscripts within the same column are significantly different, $P<0.001$.

then placed in CZB medium (Chatot et al., 1990). At second nuclear transfer, the nucleus of the constituted one-cell embryo was again transferred to previously enucleated fertilized one-cell embryos. On day 4 of culture in vitro, blastocysts were selected and transferred to the uterine horns of $8-10$-week-old ICR female mice on day 3 of pseudopregnancy ( 2.5 days after mating).

\section{Genetic analysis}

Mutations of the G9a gene in the donor TT2 ES cells and cloned mice derived from the ES cells were analysed by PCR. DNA from the ES cell colonies and tails of the clones were obtained by extraction with a buffer containing $1 \mathrm{mg}$ protease $\mathrm{K} \mathrm{ml}^{-1}$. Amplification of sequences from the wildtype G9a allele was carried out using a primer set forward: EX14F; 5'-CAGGACAGTGGGGGCTGGACGCCCATCATC and reverse: EX16R; 5'-CCGGCAGATGATCTTCTCGGTGCGGACAGC, and the targeted allele, including the neoresistance gene, were amplified using a primer set forward: G3; 5'-GGGCCAGCTCATTCCTCCACTC and mG9a127; 5'GCAGATGTGATGGCTTGGGGTAG. Twenty microsatellite markers were analysed by PCR using the specific primers described by Love et al. (1990) to confirm that the cloned mice were derived from the TT2 ES cells.

\section{Fluorescence in situ hybridization}

Fluorescence in situ hybridization (FISH) was performed on metaphase chromosomes derived from cultured lymphocytes prepared using the standard procedure described by Watanabe et al. (1996). Biotin-labelled mouse whole $X$ chromosome-specific probe was used for hybridization, and the bound probes were detected with Biotin-fluorescein isothiocyanate (FITC) painting kit (TAKARA, Tokyo; catalogue number 1187-XMB).

\section{Statistical analysis}

Data were analysed by chi-squared analysis.

\section{Results}

Donor TT2 ES cells, which had been established from a hybrid strain B6CBF1 male mouse embryo arrested at metaphase (Fig. 1a-c), were fused with enucleated oocytes using Sendai virus. After fusion, the single metaphase plate was observed in the oocyte cortex within $2 \mathrm{~h}$ (Fig. 1d). After artificial activation, $94 \%$ of the embryos formed a single diploid pronucleus after extruding the extra polar body (Table 1, Fig. 1e). The pronucleus was again transferred into an enucleated fertilized one-cell embryo in some cases to test the proposed superiority for development of using cytoplasm from a fertilized egg. When oocytes were produced by serial nuclear transfer, $70 \%$ of the embryos developed to the blastocyst stage (Table 2, Fig. 1f). The proportion of blastocysts was significantly lower in the group of oocytes produced from a single nuclear transfer (51\%).

The ability of blastocysts to develop after implantation was assessed by transferring 445 blastocysts into 36 pseudopregnant females (Table 2). The implantation rate, which was calculated on the basis of the number of embryos transferred, was not significantly different between 


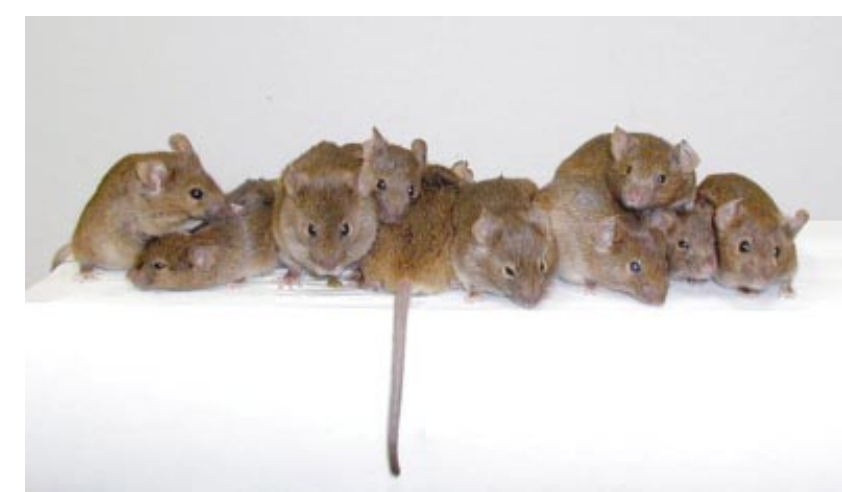

Fig. 2. Cloned mice produced from gene-targeted embryonic stem cells arrested at metaphase.

oocytes produced by serial and single nuclear transfer $(52 \%$ versus $47 \%$, respectively). Twenty-seven live pups, of normal phenotype with agouti coat colour, were recovered by Caesarean operation at day 19.5 of gestation. However, the proportion of pups produced was similar in both groups (3.2\% for oocytes produced by serial nuclear transfer versus $3.7 \%$ for oocytes produced by single nuclear transfer). Of these 27,23 pups (85\%) were successfully nursed by foster mothers and grew into normal adults (Fig. 2). None of the pups from embryos produced by serial nuclear transfer died postnatally, except one pup for which the foster mother refused nursing. All three cloned pups $(11 \%)$ that died within a few hours after recovery were derived from embryos constructed by single nuclear transfer. The analysis of 20 microsatellite genetic markers by PCR confirmed that all cloned mice were genetically identical to the donor ES cells of TT2 line.

PCR analysis using the specific primers for the neoresistance gene was used to detect mice that were derived from ES cells targeted at the G9a gene (Fig. 3). The proportions of the gene-targeted ES cells and the genetargeted cloned mice were $40 \%$ (16 of 40 cells, data not shown), and 39\% (9 of 23), respectively. The proportion of cloned mice carrying the mutation was not significantly different from that of the ES cells, indicating that gene targeting does not affect the developmental capacity of ES cells when they are reprogrammed.

The phenotype of the cloned mice was male (Fig. 4a,b), except for two cases that were apparently female (Fig. 4c,d). The 'female' cloned mice mated with the wild-type males, resulting in pregnancy and the birth of normal pups. Karyotype analysis revealed that the cloned mice were of XO genotype (Fig. 4e), indicating that the ES cell line contained cells with a deleted $\mathrm{Y}$ chromosome.

\section{Discussion}

The ability to induce reprogramming of donor nuclei is specific in ooplasm and degrades before pronuclear formation. Reports on embryo cloning from embryonic (Kwon and Kono, 1996) and somatic cell nuclei (Ono et al., 2001) showed the advantages of serial nuclear transfer. In cloned pigs, Polejaeva et al. (2000) noted the advantage of serial nuclear transfer. The results of the present study show that the proportion of blastocysts produced was significantly higher after serial transfer than it was after single nuclear transfer, and that postnatal death did not occur when serial transfer was used. However, further study is required to confirm this finding and to clarify its effects on reprogramming and development.

The survival rate of cloned pups in the present study was high: $85 \%$ (23 of 27 ) live pups developed normally with reproductive ability (Table 2 ). This finding is in contrast to the results obtained by Wakayama et al. (1999), who failed to produce clones from TT2 ES cells. The reason for this difference is unclear, but may be the result of the nature of the ES cell lines used rather than the procedures. When J1, CCE and E14 ES cell lines derived from 129 inbred strains of mice were used as donor cells, the proportions of cloned embryos developing to the blastocyst stage were not significantly different from those of TT2 ES lines. Post-implantation development was tested by transferring 332 blastocysts to recipient females. However, only one live pup, which later died, was obtained from J1 ES cells. This finding may support the contention that ES cells derived from inbred strains of mice are difficult to reprogramme sufficiently to support development to term (Rideout et al., 2000). It appears that only particular ES cells can be used as nuclear donors, although the underlying mechanisms ensuring success remain unclear.

Unexpectedly, two of the cloned mice were XO females with normal reproductive ability. As TT2 ES cell lines contain cells with a deleted $\mathrm{Y}$ chromosome (Uchida et al., 1994), the female clones may have been produced from XO ES cells. However, it is not known whether the frequency is consistent with that of ES cells.

Hypertrophy of the placenta was observed in all cases. The mean placental mass of cloned mice was $341 \pm 87 \mathrm{mg}$ $(n=27)$, which is significantly higher $(P<0.001)$ than that of the controls $(136 \pm 31 \mathrm{mg} ; n=20$, data were used when litter size was $<5)$. Somatic cloned mice are known to exhibit hypertrophic placentae (Wakayama and Yanagimachi, 1999; Ogura et al., 2000; Ono et al., 2001), indicating that defective placental function contributes to the high rate of embryonic loss. Our previous study showed that the hypertrophy was caused mainly by extensive proliferation of trophoblastic and endometrial glycogen cells in the spongiotrophoblast tissues (Ono et al., 2001). Genes controlling cell differentiation in the labyrinth (Basyuk et al., 1999), spongiotrophoblasts (Guillemot et al., 1995) and giant trophoblast cells (Riley et al., 1998; Hunter et al., 1999) of the placenta may be involved in this phenomenon. Imprinting genes may also be involved in the abnormal development of cloned embryos and extraembryonic tissue including the placenta. 

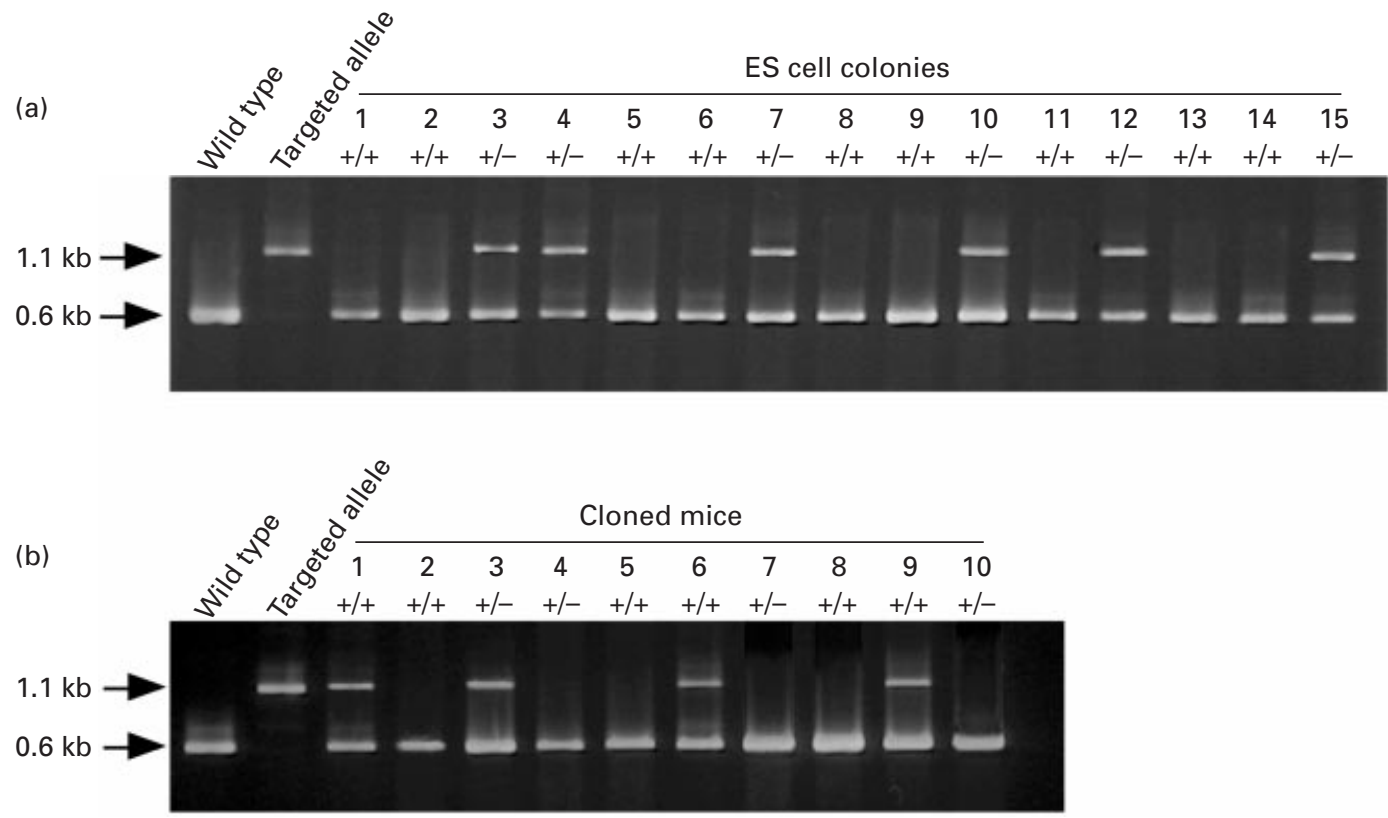

Fig. 3. Analysis of targeted mutation of G9a gene in the donor TT2 embryonic stem (ES) cells (a) and cloned mice derived from the ES cells (b). The $0.6 \mathrm{~kb}$ DNA fragment amplified from the wild-type G9a allele and the $1.1 \mathrm{~kb}$ fragment amplified from the targeted allele, including the neo-resistance gene.
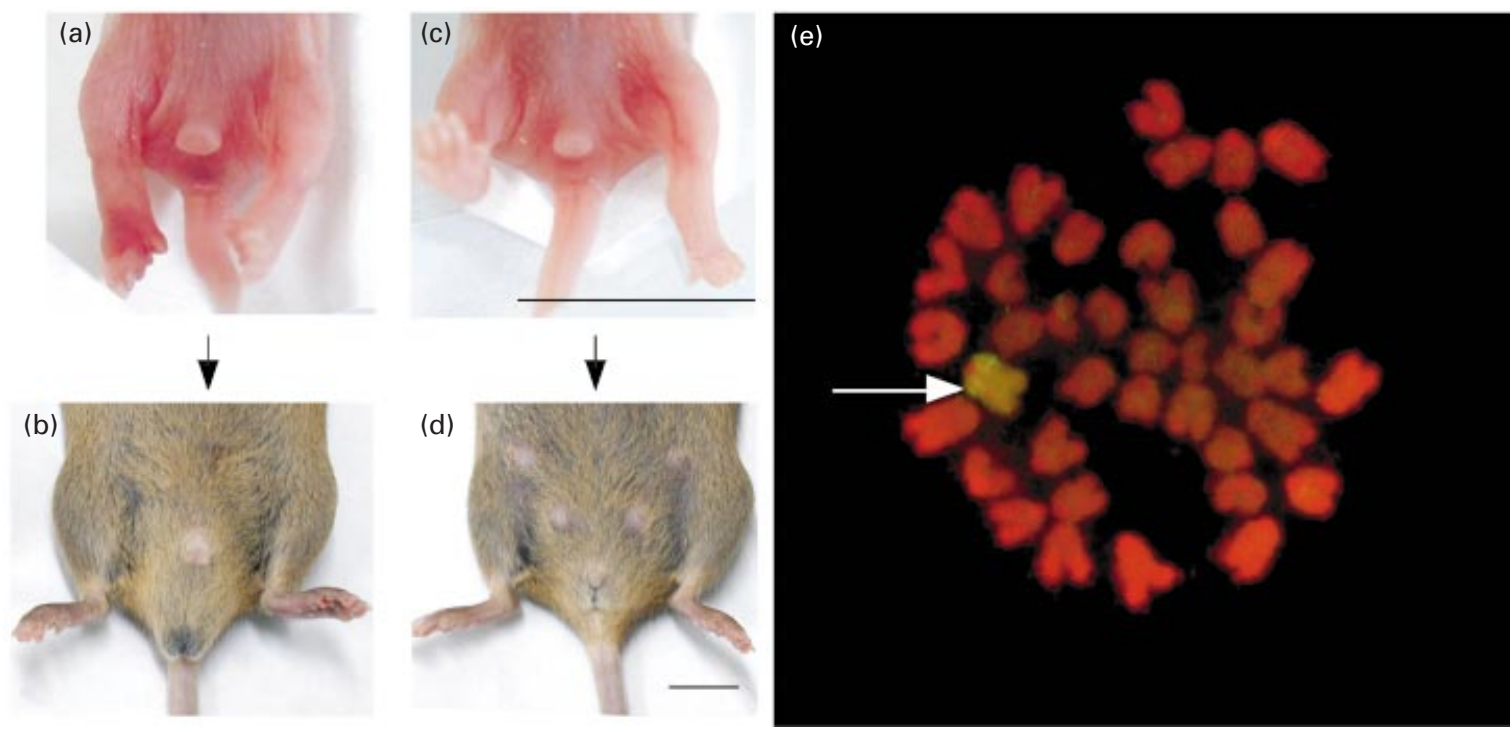

Fig. 4. Female cloned mice have $X O$ karyotype. Phenotypes of external genitalia in male $(X Y)(a, b)$ and female $(X O)(c, d)$ mice. (a,c: newborn pups; b,d: adults). (e) Fluorescence in situ hybridization (FISH) for an X chromosome (arrow) at $\times 400$ magnification in a female cloned mouse. Scale bars represent $10 \mathrm{~mm}$.

In conclusion, we have demonstrated that gene-targeted mice can be produced from TT2 ES cells by embryo cloning and that only a few postnatal deaths occur. This finding supports the contention that ES cell cloning technology can be incorporated into gene manipulation strategies, while overcoming some of the disadvantages seen in germ line transmission using chimaeras.

The authors thank D. Whittingham for critical reading of this manuscript and Y. Sotomaru for discussion. This work was 
supported by grants from the Ministry of Education, Science, Culture and Sports of Japan, the Ministry of Agriculture of Japan, the Japanese Society for Promotion of Science and Macrogen Inc. (Korea).

\section{References}

Baguisi A, Behboodi E, Melican DT et al. (1999) Production of goats by somatic cell nuclear Nature Biotechnology 17 456-461

Basyuk E, Cross JC, Corbin J, Nakayama H, Hunter P, Nait-Oumesmar B and Lazzarini RA (1999) Murine Gcm1 gene is expressed in a subset of placental trophoblast cells Developmental Dynamics 214 303-311

Campbell KHS, McWhir J, Ritchie WA and Wilmut I (1996) Sheep cloned by nuclear transfer from a cultured cell line Nature 380 64-66

Chatot CL, Lewis JL, Torres I and Ziomek CA (1990) Development of 1-cell embryos from different strains of mice in CZB medium Biology of Reproduction 42 432-440

Guillemot F, Caspary T, Tilghman SM et al. (1995) Genomic imprinting of Mash2, a mouse gene required for trophoblast development Nature Genetics 9 235-242

Hunter PJ, Swanson BJ, Haendel MA, Lyons GE and Cross JC (1999) Mrj encodes a DnaJ-related co-chaperone that is essential for murine placental development Development 126 1247-1258

Kato Y, Tani T, Sotomaru Y, Kurokawa K, Kato J, Doguchi H, Yasue H and Tsunoda Y (1998) Eight calves cloned from somatic cells of a single adult Science 282 2095-2098

Kwon OY and Kono T (1996) Production of identical sextuplet mice by transferring metaphase nuclei from four-cell embryos Proceedings National Academy of Sciences USA 9313 010-13 013

Love JM, Knight AM, McAleer MA and Todd JA (1990) Towards construction of a high resolution map of the mouse genome using PCRanalysed microsatellites Nucleic Acids Research 18 4123-4130

Ogura A, Inoue K, Ogonuki N et al. (2000) Production of male cloned mice from fresh, cultured, and cryopreserved immature Sertoli cells Biology of Reproduction 62 1579-1584

Ono Y, Shimozawa N, Ito M and Kono T (2001) Cloned mice from fetal fibroblast cells arrested at metaphase by a serial nuclear transfer Biology of Reproduction 64 44-50

Polejaeva IA, Chen SH, Vaught TD et al. (2000) Cloned pigs produced by nuclear transfer from adult somatic cells Nature 407 86-90

Rideout III, WM, Wakayama T, Wutz A, Eggan K, Jackson-Grusby L,
Dausman J, Yanagimachi R and Jaenisch R (2000) Generation of mice from wild-type and targeted ES cells by nuclear cloning Nature Genetics 24 109-110

Riley P, Anson-Cartwright L and Cross JC (1998) The Hand1 bHLH transcription factor is essential for placentation and cardiac morphogenesis Nature Genetics 18 271-275

Schnieke AE, Kind AJ, Ritchie WA, Mycock K, Scott AR, Ritchie M, Wilmut I, Colman A and Campbell KHS (1997) Human factor IX transgenic sheep produced by transfer of nuclei from transfected fetal fibroblasts Science $2782130-2133$

Tachibana M, Sugimoto K, Fukushima T and Shinkai Y (2001) SET-domain containing protein, G9a, is a novel lysine-preferring mammalian histone methyltransferase with hyperactivity and specific selectivity to lysines 9 and 27 of histone H3 Journal of Biological Chemistry 25 309-25 317

Uchida M, Tokunaga T, Aizawa S, Niwa K and Imai H (1994) Isolation and nature of mouse embryonic stem cell line efficiently producing female germ-line chimeras Animal Science Journal (Japan) 66 361-367

Wakayama T and Yanagimachi R (1999) Cloning of male mice from adult tail-tip cells Nature Genetics 22 127-128

Wakayama T, Perry AC, Zuccotti M, Johnson KR and Yanagimachi R (1998) Full-term development of mice from enucleated oocytes injected with cumulus cell nuclei Nature 394 369-374

Wakayama T, Rodriguez I, Perry AC, Yanagimachi R and Mombaerts P (1999) Mice cloned from embryonic stem cells Proceedings National Academy of Sciences USA 96 14 984-14989

Wakayama T, Tateno H, Mombaerts P and Yanagimachi R (2000) Nuclear transfer into mouse zygotes Nature Genetics 24 108-109

Watanabe Y, Yagami K, Sugiyama F, Ishida J, Murakami K, Nomura T and Katoh H (1996) Chromosomal mapping of human angiotensinogen gene and human renin gene by fluorescence in situ hybridization (FISH) in transgenic mice Experimental Animals 45 265-269

Wilmut I, Schnieke AE, McWhir J, Kind AJ and Campbell KHS (1997) Viable offspring derived from fetal and adult mammalian cells Nature 385 810-813

Received 6 February 2001.

First decision 28 March 2001.

Resubmitted manuscript received 27 April 2001.

Accepted 5 July 2001. 